\title{
Paideusis
}

\section{Teachers' Work and the Preparation of Teachers}

\section{David Corson}

Volume 13, Number 1, 2000

URI: https://id.erudit.org/iderudit/1073018ar

DOI: https://doi.org/10.7202/1073018ar

See table of contents

Publisher(s)

Canadian Philosophy of Education Society

ISSN

0838-4517 (print)

1916-0348 (digital)

Explore this journal

Cite this article

Corson, D. (2000). Teachers' Work and the Preparation of Teachers. Paideusis, 13(1), 5-19. https://doi.org/10.7202/1073018ar

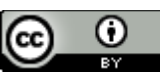

This document is protected by copyright law. Use of the services of Erudit (including reproduction) is subject to its terms and conditions, which can be viewed online.

https://apropos.erudit.org/en/users/policy-on-use/
This article is disseminated and preserved by Érudit.

Érudit is a non-profit inter-university consortium of the Université de Montréal, Université Laval, and the Université du Québec à Montréal. Its mission is to promote and disseminate research.

https://www.erudit.org/en/ 


\section{Teachers' Work and the Preparation of Teachers}

\section{David Corson, Ontario Institute for Studies in Education}

Writing in the Toronto Star, University of Alberta history professor, Andrew Gow, describes school-teaching as "practically medieval, and certainly preindustrial" in its work rhythms: "A teacher must be ready to perform at a certain time (it's hard to put off a whole class)". He argues that because teachers use their work time differently from most other people, they and their jobs are very easily misunderstood. He also likens school-teaching to university teaching (1998, p. A20).

These views from Gow invite speculation on ways to characterize a little more closely, the work that school-teachers do. How might we place teachers' work on continua that would contrast it with other kinds of work? Is teaching different from other work? If so, what are the differences? What implications might there be in all this for teacher preparation.

Although Gow's article served his own purposes very well - namely by doing something to counter the "many nasty remarks" and "more than one ill-tempered editorial page complaining about teachers' supposedly privileged working conditions" - a few things about his argument and his comparisons intrigued me. They provide the impetus for what follows.

My article begins by conceptualizing 'work' as a continuum that reaches between the poles of occupational and recreational work. Then I link these categories to two others - constrained and unconstrained occupational work - arguing that the further workers move from unconstrained to constrained occupational work, the less like recreational workers they become, and the less able they are to see work as an end in itself. Nevertheless, teachers seem an interesting exception to this. Their work is an end in itself, far removed in this way from constrained labour, even though it is surrounded by many constraints which teachers-in-training are not well prepared to meet. This suggests a need for training in ways of dealing expeditiously with the constraints that affect the meaningfulness of the work teachers do. Innovations might include some training in rhetoric, or in the skills of the stenographer and library researcher, or in metacognitive and metalinguistic skills. This article agrees with Gow's conclusion that the unusual work conditions teachers face are little understood by the wider public.

Paideusis 13:1, 2000 


\section{Occupational and Recreational Work}

One early sociologist's definition contrasts 'work' with 'recreation'. Work is a means to an end, while recreation is an end in itself: "Work is a purposeful activity performed by men [and women] in producing goods or services of value, whether for remuneration or not" (Anderson, 1964 p. 133). This distinction between work and recreation - the one a means to an end and the other an end in itself seems an important one for this discussion, mainly because I think there are good grounds to reject it.

I believe that we cannot accept this 'means to an end' interpretation of the meaning of 'work'. If we subscribe to the very practical view from Wittgenstein that 'the meaning of a word is its use in a language', then any reasonable and common instance of the word 'work' being used to describe an activity of recreation, will suggest that the 'means to an end' and 'end in itself' distinction is less than watertight.

Are there instances of recreational activities to which the English word 'work' can be appropriately applied? The recreational field of 'hobbies' suggests itself immediately. So many hobbies are conducted in workshops, using tools of work operated on workbenches. Do we refer to the activities themselves as work? The answer is that we commonly do refer to hobby activities as work, without attaching any specialist or metaphorical sense to the meaning of the word 'work'. The philatelist, for example, might say 'I am at work on my collection'. Even those who play games or exercise for recreation, describe their activities occasionally as work. Mountaineers or chess players might reflect on their activities, the former describing them as 'hard work scaling that cliff' and the latter as 'easy work disposing of our opponents'. So it seems that recreational activities can be described as 'work', even when there are no overt goods or services of value produced. And on this account, work can be both a means to an end and an end in itself.

Work becomes a means to an end when it is performed in an occupational role: as the work activity of a job. So let me use the phrase 'occupational work' for that variety of work that is instrumental to some other goal (usually the remuneration of workers, or the survival of themselves and their societies). And let me use the term 'recreational work' to describe that other form of work that is an end in itself. ${ }^{1}$

Recreational work is voluntary, in most everyday senses of the word 'voluntary'. We choose to engage in recreational work; we are not driven to it by forces external to ourselves. It is part of the nature of recreation that it ceases to exist for people compelled to pursue it. Recreational workers are free to choose the time, the venue, the duration, and the intensity of their work activity. And if they 
are not reasonably free to choose these aspects of their work, then they are not recreational workers, since their work is instrumental to some other goal.

On the other hand, occupational workers are often less free to control these intruding aspects of their work, because they are usually under contract to perform certain things. They are constrained to accept certain limiting conditions of time, venue, duration and intensity that might not be to their liking. Although in this regard, things have improved for many workers, many others are still locked into forms of work that constrain them in ways that most people still take-for-granted, as an intrinsic part of 'work' itself:

In the early 19th century, the first factory workers were forced by fines, kicks and even whips to mind the clock, arrive at work on time and live by mechanical rhythms in order to maximize the efficiency of early spinning and weaving machines. For the first time ever most people had separate homes and workplaces, and work came to be defined not just by pay, but by where it was done and when.

By 1900 , the new time-keeping mentality had produced a profound revolution for the majority of workers. No longer did sunrise and sunset mark the working day. The low-key traditional rhythms of traditional farming were banished by artificial lighting. Most of us are used to this because we have been forced to adapt. Our jobs demand it ...

Though we are poised to begin a new age based not on brute strength but on information and knowledge, as heirs of the industrial revolution we [still] equate virtue and success with hard work, and hard work with long uninterrupted hours of doing the same thing (Gow, ibid.).

Constrained occupational workers seem less able to exclude these external constraints from the meaning of the work they do. Their work is so influenced by these factors that the meaning of 'work' for them becomes an amalgam of interests, circumstances, and forces which might seem to outsiders to be separate from the work activity itself. But for the workers themselves, this work is a less unalloyed form of work than is recreational work, unless occupational workers are able to separate the work from the constraints, either in practice or by some mental adjustment that allows them to perceive the 'work' and the 'constraints' as distinct.

\section{Constrained and Unconstrained Occupational Work}

Workers differ markedly in the degree of constraint under which they work. At one extreme, for example, galley slaves or assembly line workers are subject to influences of time, venue, intensity and duration that are quite outside their control. We might call these people 'constrained occupational workers' or 'labourers'. But moving to the other extreme of the continuum, there are, for instance, many professional persons or academic researchers who can afford to adopt a quite whimsical 
and licentious approach to matters of time, venue, intensity and duration. Also, on a less prosaic level, aboriginal peoples, who follow their own traditional practices to keep their families housed and fed, tell me that they greatly prefer these work practices, that are without the externally imposed constraints of formal employment, partly because of the rich feeling of freedom that goes with them.

We might call all these different people 'unconstrained occupational workers'. For this group of workers, the meaning of 'work' seems much closer to the actual work activity itself than it is for the more constrained occupational workers, who tend to perceive the contraints affecting their work as if they were a part of that work: indistinguishable from the work itself, and intrinsic to it. In contrast, the meaning of work for the unconstrained occupational workers is very like the meaning of work for recreational workers, since recreational work is performed in an atmosphere relatively free of intruding constraints.

Robin Attfield (1984) contends that rather than being artificially instilled, 'meaningful work' responds to an essential human need, offering most people their best chance in life of the necessary good of self-respect. 'Meaningful work' for Attfield seems very like my 'unconstrained occupational work'. And 'constrained occupational work' on my account seems very like Attfield's idea of 'labour'. He argues that because meaningful work, and the self-respect that goes with it, are usually linked with having employment, then we should recognise the value of work, and plan accordingly for full employment as a high social priority. ${ }^{2}$ I am confident that it is meaningful work that Attfield prefers here, well ahead of constrained labour. He wants work that is an end in itself, or something tending more towards recreational work, on my account.

The further along the continuum workers move, from unconstrained to constrained occupational work, the less like recreational workers they become. Unconstrained occupational workers, like recreational workers, are more able to see work as an end in itself. They are able to see it as a desirable alternative to recreational work, or even as a special form of recreational work activity. Indeed, they are doubly rewarded by their work. It has the end-in-itself attraction that recreation has, and it is also well remunerated.

In contrast, the more constrained occupational workers are not always encouraged by their work to see it as much more than a means to an end, and for them the chief end is usually remuneration of some kind. Their work also has a meaning that is separate from themselves, and more likely to be divorced from their nonwork activities. 


\section{Teachers' Work}

Teachers are a little different, however. On the one hand, the constraints of school organizations, of boards of education, of ministries, of parents, of curricula, timetables, examinations, and, of course, of the student body itself, all impinge heavily on teachers and their work. Moreover, the pressures to deliver a teaching performance, at a fixed time and place, in response to all these other constraints, create unusual rhythms of work. So on the continuum that I am offering here, teachers' work is highly constrained. And when they get together, groups of teachers sometimes devote much of their talk to lamenting about these many, very real constraints. But this highly constrained conception of their work is not the view that teachers prefer to adopt themselves. From her longitudinal study of 99 teachers, Nias (1989) reports that her respondents regard their work as a core part of their very being. For these teachers, their work is their life, not just a career or a job. It is far removed from constrained labour.

Even teachers positioned more at the margins of the mainstream activities that schools do, still look for a meaning in their work that goes well beyond that found in a highly constrained job. ESL teachers, for example, often suffer constraints of status that worsen the already unusual difficulties of time, venue, duration, and intensity that they work under. Bascia (1996) reports that the advocacy work these teachers do, helping culturally or linguistically different students get respect in schools, is not formally recognized in any way in school organizations. Instead, the official role of ESL teachers is just to solve other teachers' 'problems'. They are cast in a handmaiden's role, suffering a status deficit that places almost unbearable limits on their perceptions of themselves, and of their work. Yet, in the social importance of the work itself, they are able to find exceptional significance. In particular, they find meaning in the advocacy role itself: helping culturally or linguistically different students get some share of respect and fair treatment in schools, even while their ESL teachers are often without it.

Perhaps the most constrained of all teachers, at least in the Canadian workforce, are heritage language teachers who usually operate outside normal school hours, who receive little recognition or much tolerance from those who manage school systems, and whose work is little appreciated or even much respected by other teachers. Yet, as Grace Feuerverger (1997) reports from her wide-ranging interview studies, these teachers seem to be engaged in a constant search for meaning and significance: for more support, and more recognition of the work that they do. Like any other group of teachers, they try to see a meaning in their work that is stripped of the constraints that surround it, even while enduring the constraints as 
regrettably necessary aspects of the present-day social institution that education is. As Nias (1989) observes, those who learn to live with the paradox of the constraints they work under, are the ones who feel like teachers.

Where possible, people try to work around or minimize the constraints that impinge unreasonably on their work. Because of the obligations they feel towards their students, most teachers would no doubt prefer their work to be more clearly an end in itself, stripped of the constraints that can so easily distort its purposes and diminish its meaning. To make it so, most teachers would doubtless prefer to teach in other ways, if only they could. Decades ago, Illich and Freire suggested alternative approaches to formal educational systems; and Russell and Neill offered other alternatives well before them. If only it were possible for formal education to be organized so as to exclude the many artificial constraints of time, venue, duration, and intensity that institutionalized education imposes.

Unfortunately, as it stands, school-teaching is a much constrained work activity - almost unavoidably so. Moreover, the work of teachers still bears the traces of certain archaic constraints of time, venue, duration, and intensity that have all but disappeared from most other types of work. For an illustration of these, consider again the description of teachers' work that Andrew Gow offers:

Teaching is an ancient profession much older than $95 \%$ of the jobs other Canadians do. It is based, like acting or boxing (other ancient and tiny professions) on brief, highly-charged performances and on variety, not on consistent sameness.

These spurts are preceded by lengthy and painstaking preparation, and they require time-consuming follow-up activities.

To perform at the peak of one's mental and physical powers, one must be prepared - in every way. Rehearsals, workouts, preparation - they all are necessary, not optional parts of this kind of job.

They also require different work rhythms, which are practically medieval, and certainly pre-industrial. A teacher must be ready to perform at a certain time ... (Ibid.)

Working from these very different constraints, I will sketch some conclusions in the next section about the type of preparation for the unique aspects of the work they must do, that present-day teachers might receive. Going back to my earlier discussion, to deal with these unusual aspects of their work, teachers need a form of preparation that will encourage them to be constructively critical of all the intruding constraints that can so easily detract from the meaningfulness of what they do.

For example, it seems essential that any constraints that cause teachers to see their students as a means to an end, rather than as ends in themselves, deserve critical inspection and quick removal. Young teachers need to have their youthful 
idealism supported too, so they can face the less attractive realities of their work, and so they can transform their work contexts, away from the ancient work rhythms, should they judge those rhythms to be undesirable. In some places, more critical approaches to school and society, and to pedagogy itself, are reaching into the heart of the teacher education curriculum (Beynon, 1997).

Critical approaches to studying education begin with the view that schools are not closed systems. They are not cut off from wider influences. Accordingly, these approaches start with power relations, ideologies, and systems of oppression found outside schools. They show how these things filter into schools and classrooms through the discourses that enter them. As a result, ideas about power and the use of discourse are as central to these approaches as they are to teacher education itself.

To move in more promising directions, a major task of critical teacher education is to untangle the ways in which wider structures and processes filter into educational organizations, and then into classrooms to recreate things like the following (Corson, 1998):

- ideology-producing classroom processes (i.e. distortions of reality in children's minds)

- instructional rather than educational action (i.e. seeing 'education' and 'instruction' as synonymous)

- supervisory rather than relational forms of interaction (i.e. between school administrators and teachers, teachers and students, and students and administrators)

- a reproduction of unjust socio-cultural arrangements

In response to these longstanding limitations, which are almost endemic to institutional policies and practices in education, a range of changes are recommended by those connected with the education of teachers. They cover such topics as teaching about language and power (Janks, 1997), designing emancipatory school language policies (May, 1997), dealing with power imbalances in teacher-administrator discourse (Waite, 1977), putting empowering teacher research methods to work in schools (McCarty, 1997), doing critical discourse research (Norton, 1997), and giving the priority it deserves to the use and study of oral discourse (Davies and Corson, 1997).

At the same time, all the mundane constraints of present-day institutions are not going to vanish, even in the face of firmly constructive criticism. Indeed, a critically real approach to teacher preparation would help young teachers understand all the things that make educational organizations so resistant to change; it would pre- 
pare them to deal with the vested interests that lie behind the constraints; and it would maintain their idealism, by encouraging them to reform their workplaces, where they can.

But alongside this preparation for change and renewal, a critically real approach would also prepare young teachers to give of their best, despite the constraints that impinge on their work. I am most interested here in how to provide this kind of support in teacher preparation programs. Admittedly, it is a narrow concern, compared to the broader reforms I have just foreshadowed. Yet if programs do not address it, novice teachers, who are still finding their way in the profession, might not locate the kind of critical space that they need: a space removed from the demanding, archaic rhythms that almost inevitably dominate the meaning of teaching in many novice teacher's minds, often to the exclusion of more critical issues. As I mention below, these 'archaic rhythms' that Gow hints at, mean the rehearsal of all the rather technical skills needed to prepare oneself physically and mentally for a teaching performance; and then the deployment of the embodied techniques for delivering that performance.

Although these days, teacher preparation is called 'teacher education' rather than 'teacher training', it may be that certain forms of 'training' are still needed in the preparation of teachers, as part of their teacher education, if novice teachers are to meet the "practically medieval" work rhythms that the artificial constraints of the job still seem to demand. My concern in what follows, then, is to help teachers become more efficient in handling their routine functions and rhythms: so efficient, in fact, that they are left with more energy and space to deal with all the more urgent, critical matters that their work entails.

\section{Teacher Education and Teacher Training}

It is difficult to conceive of education today without thinking about planned attempts to transfer knowledge from expert to novice, or, more properly, attempts to create conditions where novices can construct their own knowledge. And it is difficult to conceive of education today without thinking about the acquisition of a lifetransforming level of understanding, critical consciousness, and sensitivity. Nevertheless, a much more general use for the word 'education' still survives, a use that has less to do with knowledge and understanding.

In English the word 'education' was originally used just to talk in a very general way about the bringing up of children and of animals. This older use survives, as Richard Peters recalls, when we talk about 'Spartan education'. This is an instance of the older sense of the word still being used, because it is clear that ac- 
quiring knowledge and understanding, as we conceive of them, was not an important part of the training of a young Spartan. We also use education in this general way when we talk about our own forms of training, even when they have no close connection with knowledge and understanding.

The distinction between 'education' and 'training' is a useful one for my purposes here. As mentioned, some additional kinds of teacher 'training' might better prepare teachers to face the constraints of the work that they do. And perhaps these forms of training are being overlooked in the rush to provide the more clearly needed teacher 'education'.

We use 'training' in a narrow sense and in a wider way too. In the narrow sense we speak of training plants or animals, or even hair. What we mean here is 'giving the subject one disposition to act rather than other dispositions'. We often associate this narrow use of 'training' with psychological conditioning, in which subjects become instruments to the will of the trainer. We also use 'training' in a wider way, as in training a philosopher, training an observer, or training the mind. Even in these uses, though, there is still the sense of imparting routine manoeuvres and skills, without much accompanying rationale.

Until the Industrial Revolution, and the introduction of compulsory schooling in the 19th century, 'education' and 'training' were used almost interchangeably. Peters recalls 'education' being used of animals and birds trained by human beings, such as hounds and falcons, and even silkworms (1973). As mentioned, this older use for 'education' still survives when we talk, for instance, of Spartan education or of our own forms of training that do not have close links with knowledge and understanding. Today though, we would not readily speak of educating animals, and never of educating plants. But we still speak of training animals and plants.

The reasons for this change are not hard to discern. With the coming of industrialism, greater value was placed on literacy, numeracy, knowledge and skill. So, with special institutions developed to pass on these things, education came to be associated very closely with the many processes of instruction that went on in such special places. Peters says that the development of the concept of an 'educated person' in the 19th century - characterized as an all-round developed person, morally, intellectually and spiritually - caused us to tighten up our usage of the concept of 'education', because of its association with the development of such a person: "we distinguish between educating people and training them because for us education is no longer compatible with any narrowly conceived enterprise" (1973, p. 54).

What is the connection then between 'education' and 'training'? Certainly training is often used as an ingredient of education. Education will usually include 
training of some sort, as a subordinate activity, like training in the more mechanical skills of literacy and numeracy. But we can never conclude that education always requires training. Even training in the skills of literacy and numeracy can be bypassed by children appropriately motivated to teach themselves. Nor can we conclude that training is coextensive with education. Being educated demands much more than being highly trained. It involves the possession of a body of knowledge along with a conceptual scheme to raise that knowledge above the level of a collection of disjointed facts. This means some understanding of principles for the organizing of facts. In other words, we need to understand the reasons behind things, an understanding that training on its own not just fails to supply, but which it can obscure.

Having said all that, I am still suggesting that there may be some very necessary forms of 'training' that teachers do need to have, in order to deal with the occupational constraints of their work, and to deal with those constraints in a professionally well 'educated' way. This is not the place to go into much detail about what those forms of training might be, but the constraints that teachers work under are obvious enough, and they do point in certain directions. Below I spell out some of these directions, in some detail for some, and in less detail for others.

Again, Andrew Gow speaks of the "highly charged performances" that teachers have to give, which are rather like those of an actor or a boxer in their intensity; and the "lengthy and painstaking preparation" for doing the work itself. Without this preparation, our instructional performances as teachers quickly fall short of the standards expected of our profession. The performance that Gow is alluding to here is the didactic teaching act itself, although in a newspaper article he finds no space to give details of the specific preparation that performance requires.

Most formal didactic acts, that go beyond the everyday and the impromptu, require intense processes of preliminary preparation to establish principles of procedure, to regularize those principles in some useful way, and to assimilate all the necessary factual details that provide the linking content of a performance. Often this work is followed by the formal structuring of a lesson plan. Then, some private rehearsal of the teaching performance itself follows, to exercise the brain's range of memory systems and embody the principles and all the factual details. This rehearsal also embodies anew, and brings to a peak of readiness, all the sign systems relevant to the planned teaching act, that the mind controls. And natural language, of course, is only one of those sign systems.

In the wider world of work, these rhythms of rehearsal and performance are unusual nowadays, although they are not quite confined to actors, teachers, and 
boxers, in the way that Gow suggests. It is clear that other, ancient professional groups, like lawyers or politicians, still see similar preparation activities as central to their own work practices. Indeed, the highly charged performances many lawyers and politicians engage in, depend on a similar kind of preparation. And because communicative effectiveness is the essence of their own effectiveness as professionals, most lawyers and politicians are advantaged if they have acquired some training in the rhetorical arts. Moreover, because communicative effectiveness is also the essence of teachers' effectiveness as professionals, some training that embodied the skills of the rhetorical arts in novice teachers, would seem to lend itself to teachers' work as well.

Accordingly, I am suggesting that teacher education programs might include some training in a modern version of the ancient arts of rhetoric, as a regular part of the normal preparation they offer. New approaches to the old arts of rhetoric are already establishing themselves, even in the mainstream curriculum of compulsory schooling. For some, rhetoric provides a unifying force for literary discourse, so that students are trained in the art of speaking and writing persuasively about the content and style of the text they are reading (Costello and Mitchell, 1995). Part of the aim here is to turn out young graduates empowered as active citizens by this aspect of their high school education. But student empowerment would also result from a program of 'critical language awareness' that examined how rhetoric actually achieves its persuasive and seductive effects on listeners (Corson, 1999). Just getting students to look at rhetoric, from both sides in this way, is something that Antonio Gramsci (1966) strongly advocated.

Obviously teachers who are able to model these skills of argument for students are better placed to teach and critique them. But there is a narrower sense of rhetoric as well, which is still connected to persuasion, but not necessarily to logical persuasion. And it is this idea that is closer to what I am getting at here. The rhetoric that $I$ would like to see as a part of teacher training, is the ancient tradition of embodying the style and arrangement of language for the production of effects (Mitchell, 1997). There are many ways in which the communication of meaning is enhanced by the many techniques of rhetoric, whose genres range over the forensic, the deliberative, the panegyric, as well as the argumentational. These techniques can be mastered in courses of teacher training, and tried out in the practicum setting.

For example, the announcements that introduce argumentative steps in a performance ("I'll begin by outlining my talk . . ." or "I have only two points to make ...") are formal, rhetorical, language habits that few people acquire these days just from living in their own language communities. Yet they are important for 
winning and holding the attention of an audience. Also important are the choice of headings or topics, the ordering of materials, and the achievement of topical coverage and flow: things which Ong (1971) calls 'inventio', 'dispositio' and 'copia' respectively. Even more important perhaps, is the use of the non-linguistic sign systems of gesture, intonation, and presentation of self, things that we now know add or detract more than just shades of meaning from messages communicated. Novice teachers not equipped with such embodied skills and habits of presentation, could find themselves constantly re-teaching mundane subject matter, using time that might be better spent on more critical activities.

Also, to help in the practical side of preparation and rehearsal, some training in the fast-fading skills of the stenographer, or in the skills of the library researcher, might be added as part of a well-rounded program of teacher education. I am not well versed in the forms of training these workers receive, but I have enjoyed and appreciated the very welcome fruits of both forms of training on many occasions. For example, the learning of a shorthand, or some other form of quick note-taking, was once an important skill for stenographers to have. A search of the curriculum of stenography might turn up other practical skills of great relevance to the more routine work teachers do, as would a search of the skills curriculum of librarians.

Again, Gow mentions the need for "rehearsals" and "workouts" to bring performances to a peak of perfection, which suggests some sort of training in mnemonics, or in deploying other elaborate metacognitive and metalinguistic skills. Metacognition includes those learning strategies and other matters of metalinguistic awareness that allow us to control our knowledge of language, so that we can better use it to suit our purposes. For example, knowing the Greek and Latin roots of English words helps people understand and learn the meaning of new words that contain them. Furthermore, at the sub-conscious level, this embodied knowledge probably helps the brain process those words more quickly when we hear or read them (Corson, 1995).

As Bruner and Haste (1987) conclude, metacognition is an aspect of language knowledge that can be taught successfully as a skill. And this is an important insight for education to have because metacognitive activity is very unevenly distributed among people. It varies according to social and cultural background; we pick it up from the stories told to us in interactions with members of our culture. But teacher preparation can make up for this by passing on that kind of knowledge, so that all novice teachers share it. But it is really a form of training, because we cannot readily distinguish between our conscious metacognitive processes and our 
unconscious or habitual processes. We can educate with a view to improving people's control over their conscious processes, but unconscious processes we can only 'train', which, as I have argued, falls well short of true education. At the same time, the act of communication involves constant interchanges between conscious processes of control and unconscious processing, rather than control of the one by the other. To an extent, then, the training of metacognitive processes, and the education of metacognitive processes, support one another.

None of these many products of training is widely available in the curriculum of schools, and, as I mentioned, they are unevenly distributed in the general population. So teachers who have not acquired them in their private lives, can easily enter teaching without even knowing of their existence. And without those skills, they seem less well prepared to handle the occupational constraints of their profession, and to find a space for the demanding and critical responsibilities that are too often overlooked.

\section{Conclusion}

Early in this article, I argued that the further workers move from unconstrained to constrained occupational work, the less like recreational workers they become, and the less able they are to see work as an end in itself. But this generalization does not seem to apply to teachers. The critical responsibilities of their work, which includes seeing children as ends in themselves who we hope are destined to become autonomous moral agents and critically aware citizens, leaves teachers in an uncertain location in all this. They have to work within constraints of time, venue, duration, and intensity that in other occupations might distort the meaning of the work performed, and cause it to be seen as constrained labour and as a means to an end. Yet, despite the constraints, most teachers still see the meaning of their work as distinct from the constraints that surround it.

For most teachers, their work is an end in itself. Yet it is curiously surrounded by constraining features which beginning teachers are rarely well prepared to meet. Unprepared as they are, they might find more space for the more critical work they have to do if certain forms of training were to appear in their preparation programs: training in the skills of rhetoric, stenography, library research, metacognition, and metalinguistics. These and other skills could help beginning teachers cope with the uniquely different work rhythms that are an undeniable feature of teachers' work. Again these ancient rhythms are unusual in the wider world of work. And, as Gow suggests, the stresses and strains they produce for professional educators are little understood by the wider public, who never have to suffer the 
constraints that teachers endure.

\section{Notes}

1. The analytical relationship between 'occupational work', 'recreational work' and 'leisure' is not an important one for this discussion, except insofar as it bears upon education itself, especially the programmatic work that teachers engage in. In general, I agree with Harold Entwistle's view (1991), that it is a mistake to conceive of work, play, recreation, home life, political activity and social service as discontinuous. Work cannot be divorced from the rest of life. It is - as Dewey, Russell and Marx suggested - the central life activity: It has created human civilization. Education directed toward preparing children for a working life and a leisure life of quality, must be conceived in the widest possible terms to include the moral, the political and the aesthetic dimensions.

2. I believe that the goal of minimizing unemployment is an obligation responsible governments always try to meet, yet many seem indifferent to it. For example, a sample of 16 urban-industrial countries responded in very contrasting ways to the global economic upheavals of the 1970s and 1980s. They adopted two quite different directions in social policy. Goran Therborn (1986) drew up national policy profiles for these countries that highlight the two very different directions in social policy the countries followed. Some plunged into mass unemployment by adopting very similar policies, including dismantling social welfare, cutting the public service, restrictive monetary policies, tax reductions, privatization, and deregulation. But five comparable countries were able to minimize their rates of unemployment. They adopted state interventionist policies aimed at promoting full employment. Ian Shirley (1991) examines more closely the roads to success that these countries followed and the features they had in common. The successful governments saw the importance of meaningful work as a necessary good in the lives of their citizens.

\section{References}

Anderson, N. (1964). Dimensions of Work. New York: McKay.

Attfield, Robin. (1984). "Work and the human essence". Journal of Applied Philosophy. 1, pp. $141-150$.

Bascia, Nena. (1996). "Inside and outside: minority immigrant teachers in Canadian schools". Qualitative Studies in Education. 9, pp. 151-165.

Beynon, Carol. (1997). Crossing Over from Student to Teacher. unpublished EdD thesis.

University of Toronto.

Bruner, Jerome, \& Haste, Helen. (1987). Making Sense: The Child's Construction of the World. London: Methuen.

Corson, David. (1995). Using English Words. Boston: Kluwer.

Corson, David. (1998). Changing Education for Diversity. Philadelphia: Open University Press.

Corson, David. (1999). Critical language awareness. A chapter in Language Policy in

Schools. Mahwah NJ: Erlbaum. 
Costello, Paul \& Mitchell, Sally. (Eds.). (1995). Competing and Consensual Voices: The Theory and Practice of Argument. Philadelphia, PA: Multilingual Matters.

Davies, Bronwyn \& Corson, David. (Eds.). (1997). Oral Discourse in Education. Boston: Kluwer.

Entwistle, Harold. (1991). "Leisure, work and education". In D. Corson (Ed.) Education for Work: Background to Policy and Curriculum. (pp. 119-125). Clevedon, Avon: Multilingual Matters.

Feuerverger, Grace. (1997). "On the edges of the map: a study of heritage language teachers in Toronto". Teaching and Teacher Education. 13, pp. 39-54.

Gow, Andrew (1998). "Why teaching is like boxing or acting". Toronto Star. August 6, p. A20.

Gramsci, Antonio (1966 [1948]). Opere di Antonio Gramsci (Quaderni Del Carcere XVIII). Vols [-XI. Turin: Einaudi.

May, Stephen. (1997b). "School language policies." In R. Wodak \& D. Corson (Eds.), Language Policy and Political Issues in Education. (pp. 231-241). Boston: Kluwer.

McCarty, Terry. (1997). "Teacher research methods in language and education." In N. Hornberger \& D. Corson (Eds.), Research Methods in Language and Education. (pp. 227-237). Boston: Kluwer.

Mitchell, Sally (1997). "Teaching, learning and assessing argument". In L. van Lier and D. Corson (Eds.) Knowledge About Language. (pp. 205-213). Boston: Kluwer.

Nias, Jennifer (1989). Primary Teachers Talking: A Study of Teaching as Work. London: Routledge.

Norton, Bonny. (1997). "Critical discourse research". In N. Hornberger and D. Corson (Eds.), Research Methods in Language and Education. (pp. 207-215). Boston: Kluwer.

Janks, Hilary. (1997). "Teaching language and power". In R. Wodak \& D. Corson (Eds.), Language Policy and Political Issues in Education. (pp. 243-253). Boston: Kluwer.

Ong, Walter. (1971). Rhetoric, Romance and Technology. Ithaca NY: Cornell University Press.

Peters, Richard. (1973). The Philosophy of Education. London: Oxford University Press.

Shirley, Ian. (1991). "State policy and employment". In D. Corson (Ed.) Education for Work: Background to Policy and Curriculum. (pp. 146-163). Clevedon, Avon: Multilingual Matters.

Therborn, Goran. (1986). Why Some Peoples are More Unemployed than Others. London: Verso.

Waite, Duncan. (1997). "Power and teacher-administrator discourse". In R. Wodak \& D. Corson (Eds.), Language Policy and Political Issues in Education. (pp. 43-53). Boston: Kluwer. 